\title{
Beyond Mainstream Environmental Studies Track the Struggle of Environmental Issues from a Religious Perspective (Study of FNKSDA as a Form of Islamic Movement Concerning the Environment)
}

\author{
Listiana Asworo ${ }^{1}$, Nuruddin Al Akbar ${ }^{2}$ \\ $\left\{\right.$ listianaasworo@umm.ac.id $\left.{ }^{1}\right\}$ \\ Universitas Muhammadiyah Malang ${ }^{1}$ \\ Universitas Gadjah Mada ${ }^{2}$
}

\begin{abstract}
This paper wants to go beyond the study of the mainstream environment so far. This study wants to provide another perspective that environmental struggles can be carried out by combining religious symbols with the perspective of Marxism. We can trace this from the thoughts and movements of the FNKSDA (Nahdliyin Front for the Sovereignty of Natural Resources). In the thoughts and movements of the FNKSDA, clearly the environmental struggle carried out was inspired by the Marxist movement. The FNKSDA can be interpreted as the first, the concrete form of "fusion" of Islamic thought and Marxism about the importance of environmental sustainability. Second, the FNKSDA is a space for the expression of its struggle. For example, the FNKSDA made an environmental study called "Ngaji Hadist Lingkungan", "Ngaji Agraria", and "Jurisprudence and Marxism" as a concrete step in their concern for the fate of the environment and oppressed society. This is proof that the FNKSDA is not only engaged in the realm of thought or ideas but is carrying out movement actions against environmental damage while still carrying its identity. This is the uniqueness or uniqueness of the FNKSDA.
\end{abstract}

Keywords: FNKSDA, Environmental Theology, Green Marxism, Religious Environmental movement

\section{Introduction}

Religion and the environment seem to be in two polar stretches. Discussions about religion are dominated by theological studies. Meanwhile, the environment is more ideological in nature. Two terminologies that seem to have no common ground. In fact, religion and the environment are not always separated from one another. Discussing the environment, for example, is very possible to be approached with a religious perspective. Meanwhile, in religious teachings are also often taught how the environment must be treated properly.

This paper brings the spirit above, which is to go beyond mainstream studies on environment and religion. If all this time, discourses on environment and religion are dominated by studies of environmental theology, the study wants to go further, understanding how environmental theology is applied in a concrete movement. In other words, this study 
wants to explain a pro-environment movement that is motivated by a particular ideology (read: religion). Thus, the pro-environment movement has its own peculiarities.

To explain this, the FNKSDA is the right example. FNKSDA is a representation of a religious-based pro-environment movement that can be said to come out of its "standard". FNKSDA not only formulates environmental traditions based on Islamic traditions, but also attempts to integrate Islamic traditions with Marxist ideology. Islamic fusion and Marxism are the peculiarities or uniqueness of the FNKSDA.

This paper is at the same time to provide an alternative reading that has appeared before regarding the FNKSDA. If a number of previous FNKSDA academics have tended to review more of the "visible surface", this paper tries to offer a deeper reading of the thoughts and patterns of the FNKSDA movement.

Previous research on the FNKSDA, for example, was written by Fardan Mahmudatul Imamah and Abdul Kodir \& In'amul Mushoffa. Imamah for example - implicitly - classifies the FNKSDA as part of the eco-Sufism movement which incidentally can be traced to the ideas of contemporary Sufistic figures such as Hosein Nasr [1]. This analysis tends to be "premature" because if you look at the writings of the activists the FNKSDA itself is actually opposed to Sufism in the sense of "orthodox", including the idea of sufism echoed by Hosein Nasr. One of the FNKSDA activists, Roy Murtadho, for example sneered this idea of Sufism as an absrurd idea which: "hopes the bourgeoisie is willing to give up their production tools and switch to value God by living a simple ascetic style" or "expecting the social order to change itself after the bourgeoisie repents by still accumulating capital by sucking in the working class as long as it does not exceed the limits "[2]

Even if the FNKSDA can be classified as a group that propagates eco-Sufism theology, as stated by Murtadho himself, their sufism style is: "revolutionary materialist spiritualism, which does not merely invite the proletariat to be patient in poverty and become objects of suffering, but make it a subject of history, through the collective struggle of oppressed humans against the exploitation and destruction of nature ". Murtadho-style Sufism is clearly based on "Marx's materialist conception of nature, which in essence is also of spiritual value" [2]. It is very clear that the idea of Islamic fusion and Marxism is crucial here, where Marxism must be fused with the Islamic tradition, including the teachings of Sufism which are also characteristic of the Nahdliyin [3].

In line with Imamah, Abdul Kodir \& In'amul Mushoffa gave different conclusions from the arguments built by this paper, namely by stating that the basis of environmental theology in the style of the FNKSDA is the Quran, Hadith, ijma, Qiyas, and Ahlus sunnah Wah Jamaah (Aswaja) culture - in the sense of Aswaja ala NU or also called Aswaja An Nahdliyah. What Abdul Kodir \& In'amul Mushoffa stated was not entirely wrong but forgetting Marxism is a big "hole" in understanding the FNKSDA, because the idea of Marxism serves as a framework or paradigm in interpreting the Quran, Hadist or in an effort to reinterpret the Aswaja tradition so that it is revolutionary [4].

Evidence from the placement of Marxism as a paradigm of interpretation is one of them illustrated by Murtadho's statement stating that Sufism that must be developed is not an "orthodox" Sufi but a Sufism based on Marx's materialist conception.

The apostate's statement explicitly positions Marxism as a framework or paradigm for reinterpreting the tradition of sufism. Likewise, the FNKSDA interpretation of the Quran, Hadist or the Nahdliyah Aswaja tradition can be said to use the framework of Marxism as a guide for interpreting the scriptural text or reconstructing the NU tradition in a revolutionary direction. 
To straddle the FNKSDA as a pro-environment movement that has its own peculiarities, this paper will borrow a new social movement theory as the basis of a conceptual foundation. The new social movement itself focuses more on non-class ideas as a direction of struggle, for example the issue of women (giving birth to the feminist movement) or environmental issues (giving birth to an environmentalism movement) [5].

The New Social Movement itself has two dominant approaches, namely the Resource Mobilization Theory and Social Identity Theory. The theory of Social Identity itself is more influenced by the thoughts of Marxism, such as the idea of struggle, mobilization, awareness, and solidarity. This social identity theory is considered appropriate to explain the FNKSDA as a pro-environment movement that combines Islamic theology (NU) with a green Marxism approach [6].

\section{Method}

Research includes qualitative research with case study methods. The reason, because the purpose of this research is to reveal what characteristics are typical of the FNKSDA theology and movement. The case study method itself is intended for research whose study focus is a single case that wants to be discussed thoroughly or comprehensively because of its uniqueness [7].

The qualitative design helps this research to be more in-depth and focused because the object is clear, namely the FNKSDA group which has a distinctive cultural background that is "traditionalist Islam" when referring to the dichotomy of Deliar Noer[8]-[9]. Therefore, the case study method is right to be used to get answers to research that wants to understand the environmental movements typical of "traditionalist" santri, namely the FNKSDA.

In addition, the case study method also corresponds to this research mission. First, the problem formulation uses the question word how, namely how the FNKSDA formulates the idea of a typical Islamic-based environmental theology. Second, this research is contemporary or contemporary research based on specific focus and locus of research, namely the FNKSDA and the style of thought. Third, in this study researchers do not have the opportunity to control the phenomenon being studied [10]-[11]. Researchers are more trying to understand (verstehen) the phenomena that are happening. In this case the intended phenomenon cannot be captured by naked eye but through a more in-depth study of various publications and actions carried out by the FNKSDA to reveal its thoughts, namely how the environmental theology is constructed in the form of movement, and why (why) theology an environment like that articulated by the FNKSDA.

This study uses primary and secondary data sources. Primary data includes words and actions of informants (in this case the FNKSDA activists) [12]. Data was obtained through understanding various discourses delivered by the activists of the FNKSDA in various media.

\section{Result and Discussion}

3.1 FNKSDA as a synthesis between Green Marxism and Pesantren Traditions

Referring to Sheet 'Work of the Nahdliyin Front for the Sovereignty of Natural Resources (FN-KSDA) the existence of this network can be traced to the meeting that took place in the office of LkiS (Institute for Islamic Studies and Social Transformation) of Yogyakarta on July 4, 2013. It was driven and also attended by persons or institutions that are close to the NU culture such as the Gus Durian network, LkiS, Lakpesdam Jombang. 
This meeting was motivated by the concerns of these circles on the socio-political conditions that occurred in Indonesia, especially in relation to natural resource management (SDA) issues. For these circles, there has been a mismanagement of natural resources in Indonesia which has resulted in the oppression of citizens - including citizens with Nahdliyin and environmental. On the other hand, the steps taken by NU in an organizational manner are not able to resist the exploitation of these troubled natural resources. Moreover, it turns out that in a number of NU elite regions it has become part of the "evil conspiracy". From there finally came an option to establish a network called the Nahdliyin Front for Natural Resources Sovereignty (FN-KSDA).

The FNKSDA itself has two strategic frameworks, namely: first, related to actions outside NU, the FNKSDA seeks to build alliances with various other movements, including the "secular" pro-environment movement such as WALHI or movements that do not specifically promote environmental issues but are actively involved in voicing the need for better governance of natural resources such as JATAM and Desantara LK FNKSDA: 5). It can be said that the framework outside NU is advocative towards "victims" who are affected by natural resource exploitation while preventing widespread environmental destruction. Second, the movement into NU is in the nature of trying to "raise awareness" of NU citizens. It is hoped that the NU people will be either organizationally involved in NU organizations or those who claim to be Nahdliyin "open their eyes" and become more active in resisting the exploitation of these troubled natural resources.

There is a challenge for the FNKSDA to formulate a "typical" pro environment theology, namely: First; not only talking about the protection of nature but also the protection of the rights of the victims of environmental exploitation. In other words, there is still a strong anthropocentric nuance in FNKSDA theology, where theology tries to distance itself from the school of deep ecology which tends to be non-or even anti-anthropocentric. [13], Second; must be able to have a dialogue with the Nahdliyin tradition that has been deeply rooted in society. The FNKSDA chose a unique way to keep "respecting" the Nahdliyin tradition by combining or rather "fusing" between the ideas of Marxism (green) and also the tradition of pesantren.

Murtadho's statement is evidence that indicates the vital synthesis of Marxism and the pesantren tradition in the FNKSDA theology. One of them can be seen in Figure 1.1. Figure 1.1. is a FNKSDA study poster. In the poster is a picture of Karl Marx and the title of a unique study of Fiqih and Marxism: Towards Liberation Fiqih? From the title, important clues can be drawn about Islamic fusion and Marxism in the style of the FNKSDA.

Figure 1.1 FNKSDA Study Poster that Explicitly Brings Islamic Fusion Discourse and Marxism

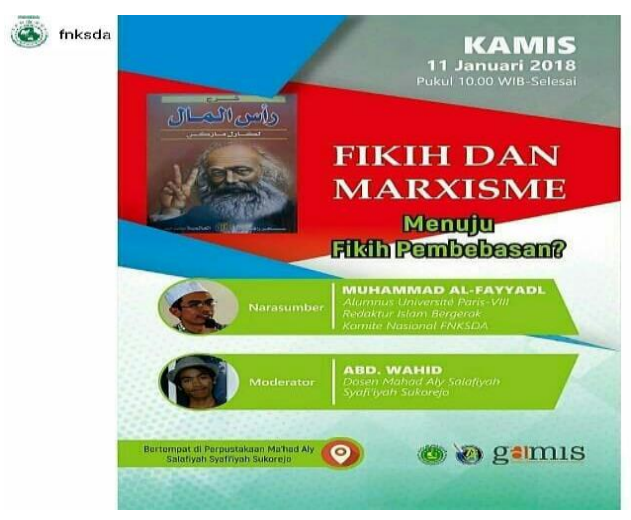


The feeling of fusion is even more pronounced when looking at the additional information from the poster: "What will be born when the book" Fathul Mu'in "meets the book" Das Kapital "? Or when the book "Al-Muwafaqat" Imam as-Syathibi met "Grundrisse"? Follow the discussion with the study group of friends Mahasantri Ma'had Aly Sukorejo, God willing, tomorrow. Sharpen the reasoning of allegiance to the clergy. Contextualize jurisprudence in the era of capitalism which is full of crisis and oppression"

Based on the explanation above, it can be concluded that it is impossible to understand the pro-environment theology of the FNKSDA without understanding Marxism, because it is the Marxist idea that serves as a paradigm for, reinterpreting, or contextualizing the way Nahdliyin have acted so far both in interpreting the Quran and Hadith or in other fields.

There are at least two important keywords in this regard, namely the idea of green Marxism and extractive capitalism. First, related to the idea of green Marxism. One of the pioneers of the idea of green Marxism can be traced to an economic figure named James $\mathrm{O}$ 'Connor [6]. Connor himself is the editor of the well-known Marxist journal, Capitalism, Nature, and Socialism, which is indeed struggling to explore the relationship between Marxism and environmental issues [14].

The idea of green marxism and extractive capitalism that is absorbed by FNKSDA and "crystallized" becomes the paradigm of their struggle. So it is not surprising if the patterned FNKSDA movement is very revolutionary. This is reasonable considering that extractive capitalism is what directly targets the peasants - who are also Nahdliyin citizens [4].

So, where is the position of the pesantren tradition in the building of theology? It can be said that the pesantren tradition plays a borrowed "language" to convey the revolutionary idea of Marxism. The FNKSDA wants to imitate Gus Dur's move to be able to carry out the first wave of transformation by spreading the idea of pluralism in the body of NU [15].

Another question that might arise is is the FNKSDA movement the same as the green marxism movement in general? The answer is of course not. Because fusion implies a "synthesis", so in addition to the radicalization of Aswaja, it can be said that there is also "earthing" of Marxism. "Earthing" is meant because Marxism uses pesantren language, religious language, and the language of the Nahdliyin tradition, there will be various reinterpretations both in the form of building green marxism theology and in its advocacy efforts through social movements. This is undeniable because pesantren language has distinctive concepts that are not in the Marxist literature. When Marxism tries to be "earthed" in pesantren language, it is like whether or not there must be an adjustment in the idea of Marxism itself so that it can be translated well and later understood by the Nahdliyin people.

In addition to theological formulations that must adopt identity politics, the "earthing" of Marxism also has implications for the pattern of advocacy and awareness that the FNKSDA is trying to do. In the advocacy process rejecting the cement factory in the Kendeng, for example, revolutionary action is certainly a non-negotiable option. However, because the FNKSDA carries a Marxist-based environmental theology that has been fused with the pesantren tradition, this revolutionary spirit needs to be "adjusted" in such a way especially when dealing with kyai who oppose their actions (such as Kyai Maimoen Zubair).

The strategy of "facing" Kyai Zubeir ala Fayyadl (general coordinator of FNKSDA) is an interesting example to be examined critically. In his article posted on the FNKSDA (Daulat Hijau) website, Fayyadl had to use a number of "yellow books" to criticize the argument of the Zubairi cleric in a language that seemed "polite", until he had to call himself al faqir (poor, poor) [16]. Even at the end of the discussion even though he stated that even if there were 
students who followed Kyai Zubair's fatwa supporting the cement factory, he could only say "You are welcome to follow this" qaul "if you are sure." He can only say: "or better again, following his "qaul qadim" which is based on the long-term benefit and synergy with the refusal of residents to the cement factory" [17]. This means that criticism here is indeed "soft" when compared to the revolutionary attitude of Marxists in general. Aswaja culture which is characterized by respect for the Kyai, for example, becomes "restraint" for the Marxian-style revolutionary spirit when applied in the field. Kultur Aswaja also made the idea of identity politics indispensable from the movement of the FNKSDA so that the discourse he carried gained a place in the "heart" of the Nahdliyin.

\section{Conclusion}

FNKSDA is a movement that seeks to develop a distinctive pro-Islamic Islamic theology. These peculiarities are reflected in the combination of Marxian-style revolutionary ideology and the NU-style yellow tradition [18]. The manifestation of the synthesis can easily be found in various activities of the FNKSDA movement such as "agrarian prayer", and "agrarian pesantren".

The peculiarities of the FNKSDA movement can also be seen from the fundamental differences with other Islamic organizations, for example with Muhammadiyah. The fundamental difference lies in the issue of tradition, the "foreign" ideological position in the development of their theology, and the format of their struggle. The "earthing" theology of the FNKSDA clearly has a difference from the more puritanical Muhammadiyah tradition for example [19]. Muhammadiyah's puritanism itself is reflected in the manhaj Tadjid (purification) that it adheres to or is now more popularized with the term Islam progressing [20]. This new spirit is clearly different from the direction and movement of the FNKSDA which is influenced by Marxism. The mahaj Tajdid-style approach for example influences the style of the Muhammadiyah movement which prioritizes a legal-formal approach (with the term jihad constitution). A style that is different from the more revolutionary (anti-formal formal) FNKSDA because for the FNKSDA which is influenced by the revolutionary ideas of Marxism, the anti-system (extra-parliamentary) pattern is considered more reasonable [21].

As a closing point that needs to be underlined is that with the presentation of the typical environmental theology of the FNKSDA, it is hoped that this study will be able to contribute to the discussion of the academic world regarding the relationship between religion and the environment which has not been well elaborated. In closing, it is not wrong to call the FNKSDA movement representation of Islamic groups that are not only able to form a sophisticated pro-environment theology by adopting a number of elements from Marxism, but also trying to implement the ideology into the level of praxis through various activities carried out by the FNKSDA so far.

\section{References}

[1] I. F. Mahmudatul., "Menghadapi Kapitalisme: Pendekatan Eco-Sufism dalam Gerakan Environmentalisme di Indonesia," Kontemplasi, vol. 5, no. 1, 2017.

[2] M. Roy., "Tasawuf dan Pembebasan," 2018.

[3] H. Moeflich, Islam \& Transformasi Masyarakat Nusantara. Depok: Kencana, 2017.

[4] K. Abdu and I. Mushoffa, "Islam, Agrarian Struggle, and Natural Resources: The Exertion of Front Nahdliyin for Sovereignty of Natural Resources Struggle Towards Socio-Ecological Crisis in Indonesia," KarsaJournal Soc. Islam. Cult. 
[5] R. Singh, Gerakan Sosial Baru. Yogyakarta: Resist Book, 2010.

[6] L. M. J., "Ecological Marxism," 2014.

[7] The Practice of Social Research. Belmont, CA: . : Thomson Wadsworth, ., 2007.

[8] A. Luthfi., Islam and the Secular State in Indonesia. .

[9] Rumadi., Islamic Post-Traditionalism in Indonesia. Singapore: ISEAS, 2015.

[10] Pawito, Penelitian komunikasi kualitatif. Yogyakarta: LkiS, 2007.

[11] A. M. Yusuf, Metode Penelitian Kuantitatif, Kualitatif \& Penelitian Gabungan. Jakarta: Kencana, 2014.

[12] Lexy J. M, Metodologi Penelitian Kualitatif. Bandung: Remaja Rosdakarya, 2008.

[13] M. Z. E., Contesting Earth's Future: Radical Ecology and Postmodernity. London: University of California Press, 1994.

[14] T. Douglas, The Promise of Green Politics: Environmentalism and the Public Sphere. Durham: Duke Univeristy Press, 1999.

[15] N. Ahmad, Merajut Damai dalam Kebinekaan. Jakarta: PT Elex Media Komputindo, 2017.

[16] M. Al Fayyadl, "Memahami Progresifnya Muhammadiyah,” 2015. .

[17] M. Al Fayyadl, "Menakwil Penyikapan Mbah Maimoen Atas Kasus Semen.," 2017. .

[18] S. Utuhena, Historiografi Haji Indonesia. Yogyakarta: LkiS, 2007.

[19] A. M. Mulkan, Kiai Ahmad Dahlan: Jejak Pembaruan Sosial Dan Kemanusiaan. Jakarta: Kompas, 2010.

[20] Q. Zuly, "Muhammadiyah Studies: Reorientasi Gerakan Dan Pemikiran Abad Kedua." Kanisius, Yogyakarta.

[21] D.Hal and E. H aberkern, Karl Marx's Theory of Revolution. New York: Monthly Review Press \& Center for Socialist History, 2005. 